\title{
Improving the school library for IB students: a case study at The British International School, Jakarta
}

\author{
Hanna LATUPUTTY, Senior Librarian, \\ Secondary Resource Centre, The British International School, \\ Tangerang, Indonesia
}

\begin{abstract}
The background of this research is firstly to evaluate the current services and facilities in the secondary library since there is a plan to extend the library building among the school projects. The outcomes of this research would be good feedback for the library staff to improve its services and facilities. Secondly, some colleagues on ECIS listserv have been discussing the need for IB guidelines especially for those who due to commence the library for IB programme. This paper is not intended to be a guideline, but a sharing work to those who are concerned with the IB library to find different perspectives from a secondary school library at The British International School, Jakarta. A survey to gain feedback has been conducted using a qualitative method. The findings and the profile of the library are discussed in the same section to help the reader understand the real situation and the feedback from the respondents. This paper, expectantly, would be a valuable reference for any school libraries particularly those who run or plan to have a library for the IB Diploma programme.
\end{abstract}

\section{Rationale}

The British International School (BIS) has provided the International Baccalaureate (IB) program for Diploma since 1997. The secondary library started to build up its IB collection as a result of the demand of students' needs. In partnership with the IB coordinator and teachers, the librarians endeavoured to fill in the information needs for students in various IB subjects.

Having had the IB programme for eight years, it is time to evaluate the support that the library has given. The outcomes of the research may provide valuable feedback to consider in planning the extension of the secondary library, which is planned for 2006/7.

\section{Purpose}

The main purpose of this paper is to evaluate the secondary school library services and facilities for IB students and to suggest some improvements for better services and facilities. 
The relevance to professional practice is to give fellow librarians other perspectives of the current practices at BIS and to enable librarians at schools who are about to start the IB to compare their services and facilities.

\section{IB Programme at BIS}

The International Baccalaureate: Year 12 \& 13 Curriculum September 2004 2006 booklet stated that:

The International Baccalaureate (IB) programme is a coherent twoyear pre - university course leading to: either the full IB Diploma or the separate subject IB Certificate. In order to gain the full IB Diploma, students are required to study six (6) subjects from the program the school offers three (3) subjects must be studied at Higher Level (HL) three (3) subjects must be studied at Standard Level (SL)(p.4)

Furthermore, it mentions the additional requirements that students:

o write an Extended Essay in a subject of their own choice, to provide students with a chance to become involved in independent research.

The Extended Essay is defined as an in-depth study of a limited topic within a subject. Its purpose is to provide students with an opportunity to engage in independent research at an introductory level and in a topic of their choices. The length of the Essay should be about 4000 words and it is intended to represent about 40 hours of individual students work (p.7) 
o complete a Theory of Knowledge course, to give students time for critical reflection on their studies.

The Theory of Knowledge course is a key element in the educational philosophy of the International Baccalaureate and is therefore obligatory for every Diploma candidate. The purpose of the programme is to stimulate critical reflections on the student's knowledge and experience both inside and outside the classroom. It is 'philosophical' in the sense that the course encourages students to acquire a critical awareness of what they and others know, through analysing concepts and arguments and the bases of value judgements(p.8)

o participate in CAS (Creativity, Action, Service) throughout the programme, to give students an opportunity to pursue their interests into a wider sphere than their immediate school environment. It was written that "CAS is a fundamental element of all Diploma students' programmes and each IB school designs its own CAS programme to meet the prescribed aims of CAS” (p.9)

Table 1. Subjects offered for IB students

\begin{tabular}{|l|l|l|}
\hline Group 1 & Language A1 & $\begin{array}{l}\text { English, Indonesian, Korean } \\
(\mathrm{HL} / \mathrm{SL})\end{array}$ \\
\hline
\end{tabular}




\begin{tabular}{|c|c|c|}
\hline Group 2 & Language B & $\begin{array}{l}\text { French, German, Indonesian, } \\
\text { English (HL/SL), Spanish, French } \\
\text { (ab initio SL) }\end{array}$ \\
\hline Group 3 & Individuals and Societies & $\begin{array}{l}\text { Business and Management, } \\
\text { Economics, Geography, History } \\
\text { (HL/SL) } \\
\text { Information Technology (HL/SL) }\end{array}$ \\
\hline Group 4 & Experimental Sciences & $\begin{array}{l}\text { Biology, Chemistry, Physics } \\
\text { (HL/SL) } \\
\text { Design Technology (HL/SL) }\end{array}$ \\
\hline Group 5 & Mathematics & $\begin{array}{l}\text { Mathematics (HL), } \\
\text { Mathematics Methods (provisional } \\
\text { SL) Mathematical Studies (SL) }\end{array}$ \\
\hline Group 6 & The Arts and Electives & $\begin{array}{l}\text { Music, Theatre Arts, Visual Arts } \\
\text { (HL/SL) } \\
\text { A second subject from Groups } \\
\text { 2,3,or } 4 \text { (HL/SL) }\end{array}$ \\
\hline
\end{tabular}

\section{The Research}

The target audience of respondents was the current Year 13 students who have been studying in the IB Diploma programme since Year 12 and have finished their Extended Essay, with the assumption that they have experienced the research process that involved them using library services and facilities. 
In the beginning of research planning, a further target of respondents was IB Alumni who have finished their IB studies to give their opinion about libraries' services and facilities. However, they were not in the country and interviewing through email, was problematic. Having IB alumni as respondents is a good future topic, especially if the researcher has flexible time to research.

This paper applied the qualitative research in its methodology approach. The respondents were six of thirty-eight IB students. As Pendit (2003, p.192) said the qualitative research uses a small and non - representative sample. The respondents were asked about how they used the library and all the other aspects of the library's services and facilities. However, since the time when this research was conducted was a busy time for Year 13 as they had to complete Extended Essays, coursework and do revision for the coming final examinations, only four of them were available for a follow up interview. The Libraries’ Manager, Mr Stuart Crouch, and IT Manager Mr Satrio Indrianto, were asked to give their opinion about related topics.

One of basic principals of qualitative research that Pendit (2003) stated was "all aspects should be seen in its context, as an attempt to give the explanation and understanding" (p. 197) which means that the research is not generalizing what an IB library should look like since it would be rigid to find two identical libraries. The research is only relevant to the secondary library at BIS, particularly in how IB students use the library, related to the facilities and services.

\section{Secondary Library: profile and findings}

The findings of the research have been divided into the following areas: 
- Accommodation

- $\quad$ Resources: Fiction, Non-fiction, Periodicals, VHS/VCD/DVD, CD ROM, Vertical File

- Information and Communication Technology (ICT): The Library System and The Internet

- $\quad$ Staffing

- $\quad$ Research/library skills

- $\quad$ Point access

\section{Accommodation}

The secondary library has two floors in the Humanities building block. On the ground floor are the collections for Reference, Non Fiction, Fiction, current Periodicals and Newspapers. There is a photocopy machine for student and staff use. The library has eight study desks and thirty-two chairs for study. Sometimes the library is also used as a classroom either by subject teachers or the librarian. There is no a silent study area for students although Green (1999) said that "students working alone need an area where they can study and research individually in peace and quiet” (p.7). One of the respondents also mentioned that he sometimes found the library had a lot of noise that disturbed him from his individual study. However, most of the respondents enjoyed the library and admitted that it has a good environment. It was obvious why the students come to the library to do their coursework and homework. They prefer working in the library instead of their common room and secondary school foyer. At this point, the library has played its role to 
meet one of its program goals (Secondary Library Handbook, 2005) which is to provide an attractive, comfortable working environment for users (p.1, Section 1)

The library opens from Monday to Friday at 7.30 to $4 \mathrm{pm}$ including break and lunch time. The students admitted that the opening hours were satisfactory. It seemed that they were not expecting the library to be open at the weekend or for longer hours after school hours.

Year 12 and 13 students are allowed to borrow ten items for two weeks. After two weeks, they are able to renew the materials if they still need them. They were pleased with this rule except that the loan period for materials needed for coursework and Extended Essays should be extended since the books are needed for more than two weeks.

A security system is placed next to exit door. The security gate that was set up in 1997 helps the librarians to monitor the materials in the library. As Doggett (2000) mentioned, "such a system attempts to keep students from removing materials from the library without checking them out" (p.117). The secondary library used the electromagnetic systems that require a security strip be placed in every book. The application of the security gate proved what Doggett (2000) said that the students think "it is funny to put an unchecked - out book in an unsuspecting friend's book bag. Some students also found out that they can hold books over their heads and walk out without beep" (p.117). However, the existence of the security gate has reduced the amount of lost materials from year to year.

On the second floor, the library keeps all the past issues of Periodicals and a collection of Teacher Resources, Adult Fiction and Audio Visual materials like audio cassettes, video cassettes, DVD, one TV, VCD, DVD player and an audio cassette player. 
The AV collection and the player are kept in a corner near to the adult fiction. This is not ideal, as when the students or teachers play a video or television for their school project, the sounds is heard from downstairs. Green (1999) stated that "ideally this (audio-visual room-HL) will be separate, bookable room, adjacent to and under the supervision of the library” ( $p 7)$

The second floor is only for Years 12 and 13 and Adults because of the limited space and for reason of supervision. With year 12 and 13 students, it was assumed that they would work at the two computers or browse the novels. The rationale for having the Adult Fiction and the Teacher Resources upstairs is that collection is developing and the library lacks space in other areas. Libraries’ Manager, Mr. Stuart Crouch has pointed out that the Adult Fiction section does not contain 'adult' books. He also mentioned the problem of having the adult fiction upstairs, “...and the problem with that is that people who are not in years 12 and 13, don't have free access to those books even though intellectually, developmentally they are able to read them" (personal communication, April 29, 2005)

Conclusion:

o The students enjoy the library's environment, although they need space for their individual study. The library should have separate rooms for private study, discussion/teaching and audio-visual facilities. This situation will stimulate a more positive environment not only for IB students but also for other users who wish to use the library facilities effectively without disturbing, or being disturbed by, others. 
o The operating hours, which are 7.30 to $4.00 \mathrm{pm}$, from Monday to Friday, are ideal for IB students.

o Year 12 and 13 are allowed to borrow ten books for two weeks. They feel this is adequate, however, they also feel that the loan period should be extended.

\section{Resources}

The library collection contains Reference, Non Fiction, Fiction, Periodicals, Newspaper, Teacher Resources, Maps, Photos, Postcards, Posters and Audio Visual collections such as audiocassettes, videos (including VCD and DVD). The Senior Librarian has been in charge of the acquisitions process for the last two years. Publishers catalogues, professional publications such as School Librarian, Access, Viewpoint, TES BOOKFIND, suggestions from teachers, students, parents, Amazon.co.uk are used to select the materials that meet the needs of the curriculum at all levels and students' recreational readings. Teachers are requested to select library materials from publisher catalogues but only very few take this opportunity.

In year 2004, a collection review has been carried out. This has allowed the library to plan efficiently for a large order to add to the library collections. The Senior Librarian firstly studied the curriculum for KS 3 and KS 4 and noted all the topics that are studied in all subjects. Secondly, she compared the list with the current collection to see what the library has and the 'holes' that need to be filled. In fact, the subject allocations were found to be disproportionate, especially for the I/GCSE and IB collections. For example, a topic under Resistant Material and Systems and Control for subject Design and Technology, both students in KS 3 and IB Diploma (Group 4 Experimental Science) were 
learning about Computer Aided Design and Computer Aided Manufacture. Despite not having any books about it, the content of the books should be different for each level.

This collection review helped the librarian in selecting appropriate materials for each level. Is is anticipated that through using this collection review the collection will become more balanced and meet the curriculum taught in all levels at secondary school.

Table 2. Secondary Library Collection

\begin{tabular}{|l|l|}
\hline Fiction & 4574 \\
\hline Non -fiction & 9182 \\
\hline Periodicals & 2370 (42 titles) \\
\hline Audio - cassettes & 93 \\
\hline Audio visual & 30 \\
\hline DVD & 95 \\
\hline Compact Disc & 119 \\
\hline Maps & 24 \\
\hline Photos & 47 \\
\hline Postcards & 4 \\
\hline Posters & 37 \\
\hline Reference & 767 \\
\hline Teacher Resources & 915 \\
\hline Video & 544 \\
\hline VCD & 118 \\
\hline Extended Essays & \\
\hline
\end{tabular}


Following is more detailed information of the library's collections including Fiction, Non Fiction, Periodicals, Reference, VHS/VCD/DVD/ CD ROM, and Vertical File.

\section{o Fiction}

The library's collection for fiction is from many genres. One of the respondents was happy with the collection, saying that he borrowed library books instead of buying book at a bookstore. Nevertheless, another respondent acknowledged that there were some old titles that need to be thrown out as it creates grim impressions for the collection. While Stuart Crouch pointed it as a negative part of the library " that both senior fiction and the ordinary fiction section first of all they're split into two physically, which they shouldn't be. And the second part is they are very small, especially the fiction upstairs. (personal communication, 29 April 2005).

o Non Fiction

Most students used the non-fiction collection for their study or research. They found it useful although some of them were not able to find the books they needed for Extended Essays. To correct this problem, the library welcomed any suggestion from students who needed more resources for their specific topic, The library then undertook to order the titles from local bookshops. Another option utilised was the student buying the resources they needed and the library reimbursing their cost. These kinds of resources enrich the collection as they take the collection beyond the core curriculum collection. Stuart Crouch found the non-fiction collection was a positive part of the library: " that nonfiction stock is quite good. We have non-fiction books, periodicals, online databases, reference materials and AV materials”(personal communications, April 29, 2005) 
Borrowing fiction and non-fiction books is another reason why the students came to the library. For those who love reading, our collections met their requirements. For instance, one of the respondents said that he borrows the novels he would buy from the library. However, in a certain section for Non Fiction, they were unable to find resources they needed for their Extended Essays. An example, the collection was poor in the areas of theatre, stage materials, staging or Japanese print. Only a few students came back and consulted with the librarian about how could they get the resources they required. Some resources were able to be secured before the required time.

\section{o Periodicals}

We subscribe to forty-two titles of periodicals both from local and overseas suppliers. We attempt to subscribe periodicals for each subject. We subscribe, for instance, to The Times Literary Supplement (TLS), The English Review for English Faculty, New Scientist, Chemistry Review, Chem Matters, Focus for Science Faculty, Teaching Math and Its Application for Mathematics Faculty. It was decided to send the periodicals to the appropriate faculty after a certain of time kept in the library. IB World is useful for IB students as it helps them to understand and know more about IB application and activities around the world.

o Reference

IB students mostly used the dictionaries from the reference collection. The collection itself covers most of the curriculum courses on offer. All the collection would stay as 'Reference Only’.

o VHS/VCD/DVD 
This collection is used for teachers only. Many titles were for PSHE (Personal Social and Health Education) use and others were for History. IB students used a lot of History AV materials for their courses. Many of them were watched in the class with teachers or they brought it home with the teacher's permission. For acquisition, the library tended to order DVD rather than VHS or VCD as according to Doggett (2000) “A DVD provides faster random access and longer shelf life than a videotape. DVD will become standard very soon, (p 118)

o Online services:

- The Encyclopæedia Britannica Online Services are online informational services provided by Britannica, consists of Encyclopædia Britannica; Britannica Student Encyclopedia; Britannica Internet Guide; Journals and Magazines; Video and Media and Merriam-Webster’s Dictionary and Thesaurus.

- Global Newsbank Databases

The library subscribed the product with statistics and the following newspaper: Times/Sunday Times (London), NY Times, and Sydney Morning Herald.

Unfortunately, not many IB students were aware of these two products. They knew about these but never used them for their research or they had never known about them.

o CD-ROM

As the school has workstations with Internet connections, the students do not use the CD-ROM collection any longer. The title which were highly used in the past were 
Encyclopædia Britannica CD; Microsoft Encarta Encyclopedia; The World Book Multimedia Encyclopedia; Microsoft Encarta Interactive World Atlas 2000; Flagtower's World War II; Yorkshire Television's World War II: Sources and Analysis; The British Library’s Medieval Realms: Britain 1066-1500; Flagtower's A History of Medicine.

o Vertical file

The library has a vertical file system that consists of the topics studied by students. Regular weeding is carried out in order to remove unwanted topics or to add a newsworthy or local topic. For instance, we have a clipping of Current Affairs in Indonesia 2002. It consisted of Accidents; Disasters; Environment; Floods; Economic Conditions. The library also had Bomb Blast in Bali: October 12, 2002 and Jakarta (2003). Jakarta had been a topic under Humanities subject for KS 3 as well as all the topics in Current Affairs in Indonesia 2002. The library is now preparing a file for the big disaster in Aceh that happened in December 26, 2004 and Nias earthquake that happened March 28, 2005. As what Yesner and Jay (1998) "local history, government, and special events; clippings on a new topic until publishers catch up; and esoteric material on standard or elusive curricular topics all prove useful and worth their investment of time”. (p. 177)

IB students used this collection, especially for History, and their subject teacher told them that the library had the articles in Vertical File.

Conclusions:

o The librarians should be aware of the Curriculum taught in KS 5 (Years 12 and 13), when developing the collection. It would help them in selecting the appropriate titles that meet students' needs in Years 12 and 13. 
o It is an advantage for the librarians to do the collection review to help them balance the collection, especially for the content of the topic books for Key Stage 5.

\section{Information and Communication Technology area}

o The Library System

The library system, Alice for Windows has been used for many years since it was known as OASIS. The library has three stations for OPAC. The students felt confidence using the computer catalog to find resources. Although the library did not hold a library orientation for them when they were new, they found using Alice for Windows OPAC easy and pretty straightforward. The only problem was sometimes they were unable to locate the books on the shelves. BIS is now in the process of installing a new library automation system. We have also invested in Brief Record Upgrade (BRU) and hope to maintain a more accurate of database from now on.

\section{o Internet}

The school installed Local Area Network (LAN) several years a go. According to Doggett (2000), "a LAN is a group of interconnected computers that can share software, date and printers, as well as track student progress and keep an inventory of hardware attached to it” (p.150). All the workstations have Internet connection, Microsoft Office tools such as Ms Word, Excel, and PowerPoint etc. The library has seven workstations that also connect to two printers and a scanner (attached to one computer). There are also two workstations upstairs for student use. 
IB students come to the library to use the computers to browse the Internet for information for their research. According to Green, "it was obvious that the Internet is fast becoming a vital resources in all school and college libraries” (p.17) because they also use the computer to check their e-mail, to type up their work and print it. A respondent said that sometimes she had to queue when she needs to work with the computer because all the workstations were occupied by other students.

An interesting factor when discussing the computer with the respondents was that all were complaining about the Internet. They found the Internet is very slow, often crashes or even it does not work, sometimes they cannot login their username and password and sometimes they have to queue since all the units are occupied. The Libraries' Manager also mentioned that IT at BIS was very poor, very old, very undeveloped.

According to IT Manager, what caused the problems above are:

o Electricity problems

o Improper computer treatment especially when the computers should be removed from one place to another

o From user's perspective: less of sense of belonging, sometimes mistyping the username and password that blocked them from using the computer, forgetting the password; incomplete installation although they were not permitted to install any software onto school computers

o The computers themselves need to be replaced

o High expectations from the user while the technical support could not afford it. 
The IT application is another interesting topic to discuss since it covers complex aspects of the whole schools. It relates to the decision-maker; the IT steering committee; budget; IT support and many more.

However, to improve the complex problem faced in the library and school, it was suggested to have training for the users those were students, teachers and staff. As Green (1999) said "they (16 to 19 students-HL) cannot be expected to do so efficiently without effective training” (p.10). Green also suggested conducting the training session with the ICT department, on particular research and information skills to support the students. Not only how to retrieve the information effectively, but also how to use and maintain the use of computer was one of the important part to be included in the training. This also applies to staff.

Conclusions:

o The ICT facilities should be reviewed and upgraded in a certain period of time to follow the IT development and especially to meet the students' need.

o The management of ICT maintenance should be improved by having good communication and transparency among people who are in charge of school's ICT

o The library staff should have appropriate training for using the new library systems.

\section{Staffing}

The library has a Libraries' Manager, a senior librarian, and three library assistants. The Libraries' Manager and Senior Librarian are stationed on the ground floor 
with a library assistant, while the other two library assistants are upstairs doing the technical processing.

Most of IB students were pleased with the services given by the librarians. They found the librarians were helpful, nice, readily answer their questions and close to students. The Libraries’ Manager stressed the library has good staff who help the students, although he mentioned that the assistants do not have strong enough personalities to deal with the students. This is illustrated when many students are noisy and usually the Libraries’ Manager needs to intervene to reduce noise. This may be because the students perceive him as a teacher, while the other staff do not have this persona. This is an area that the assistants could improve with support from the Libraries' Manager. Green (2000) said that "although 16 to 19 students are young adults and attend school or college by choice this does not mean that they always use your library in a responsible and positive manner" (p. 12) The assistants are capable of dealing with an individual approach. However, they do not have the confidence to maintain overall supervision of the library.

Conclusions:

o The staff should maintain their good service to student as helpful librarians. However, they could improve their confidence in terms of overall supervision of students.

Research/library skills 
The IB students hardly found problems when they prepared the coursework and Extended Essays related to the research skills. The only problem they faced was lack of books or information they need to support the topic they have been researched.

Some of them had already been given study skills when they were younger in their previous school. If during the research they had a problem, they would see their supervisor to consult, so that they admitted that they did not have any serious problem when they finishing their Extended Essays or other coursework. This would be interesting when the IB result come out to see how the result of their Extended Essays and Theory of Knowledge they have been done.

Even though the finding showed the students did not need a research skill, Dubber (1995) pointed that information skills are crucial for young people:

o To help to equip them for the changing information world of the classroom and beyond

o To help them to become self-motivated independent learners with the confidence and skills to find out for themselves and to take ownership for their own work and learning

o To deliver the statutory curriculum expected by the government, in England, Wales, Scotland and Northern Ireland

o To improve the quality of children's learning and to meet the requirements of the inspection process (p.5)

Conclusions: 
o It would be an advantage for IB students to have Research/Study Skills when they are at Year 12 although they said that they did not have any problems with researching when they did they Extended Essays or other coursework.

o By giving the research skill/information skills the library would standardize the students with the skills since not all the students had skills taught in their previous school.

\section{Point Access:}

One of library services was being a point of access for students who need more information, which the library would not be able to supply. This is one of the library's program goals stated in Secondary Library Handbook (2005) that mentioned the library is "To act as a point of access to a range of resources within and beyond the school building. This include persons, materials, equipment and facilities where possible given the restrictions of living in a foreign environment" ( p.1, Section 1). The information could be obtained outside the library, from national library, company library, and special library or even from people who were expert in their field.

The students would come to the library and discuss their information needs with the librarian. The librarian would suggest various options, and refer them to the appropriate local resources - including people the student may be interested in contacting. If required, the librarian would contact the person or company to make appointment for the students.

There are some students who use this service particularly when they have obstacles with resources. For example, a student who needed information about a tribe from Sumatra contacted the school librarian, who in turn contacted a librarian at the 
University of Indonesia. Needs, resources, availability and access were discussed and an appointment was made for the student to discuss it with the University librarian. The student was able to source the information he needed, and used it the next day in his research.

Conclusion:

o The Point Access is one of library services that works very well in the Secondary Library. Many students benefit from the librarians, who help them get more information or who contact other people outside the school community. The library itself is limited in its collection.

o The networking of the librarians plays a crucial factor in supporting this service. The more people the librarians know, the more access the students have.

\section{Conclusion}

A recent preliminary visit in preparation for CIS accreditation touched on the need for an extension to secondary library facilities and services. In the light of these recommendations and the results of this research, when the library is extended, it would be an advantage if:

o The librarians consider having extra rooms to separate the audio-visual collection and AV hardware and a private study area for IB students.

This will mean that several distinct activities can take place in the library

simultaneously. The IB students will not disturb others, nor will they be disturbed by other library users. Small groups of IB students will be able to use the AV facilities, or take part in group discussions. 
- Collection development should be balanced to cope with all of the topics taught in KS 5 (Years 12 and 13).

By doing so, students will view the library as a more useful resource, and will be encouraged to suggest items for purchase that will have a direct impact on their work.

o Online services need to be promoted

The school has invested large sums of money in this area. At present, many students are unaware of the resources that are available to them. The installation, development and subsequent promotion of the new library automation system will mean that bibliographic OPAC searches will direct the IB students to online databases, appropriate educational websites, in addition to the print and electronic media housed within the library facilities.

o Librarians are encouraged to be more confident in dealing with the students' misbehaviour.

The Libraries’ Manager will support that library staff and use INSET to suggest ways in which positive student behaviour can be fostered.

o Staff and teachers should work together in terms of maximizing the use of the secondary library's services and facilities

They should work cooperatively for instance, in collection development and planning research/study skills. In research/study skills, instead of teaching how to research, the librarians and teachers also need to teach students how to apply the information literacy correlated with the subjects studied. The skills also cover how to use the library's services and facilities effectively and efficiently.

\section{Shortcomings}


It would have been more profitable to begin the interview process earlier in Year 13. The research timing was not appropriate for our year 13 students. They have a busy time preparing their coursework and revising before the examinations time. It might also have been meaningful to interviews a broader cross section of students.

\section{Credits}

The author would like to thank Year 13 who have given some times in the middle of their busy time especially for Davide Besana, Haang Kim, Luis Esguiera, Maria Titania, Rifky Sofyan, Sitjke Schippers. Also to the Libraries’ Manager, Mr Stuart Crouch and Mr Satrio Indrianto for their time to answer all the questions. 


\section{Reference}

Doggett, Sandra L (2000). Beyond the Book. Englewood:Libraries Unlimited

Dubber, Geof (1995). Teaching Information Skills. Swindon: School Library Association

Green, Dawn (1999). SLA Guidelines. Moving up: The Library Resource Centre 16 to 19. Swindon: School Library Association

The British International School. International Baccalaureate Years 12 \& 13 Curriculum: September $2004-2006$

The British International School. Secondary Library Handbook 2005.

Pendit, Putu Laxman, Ph.D (2003). Penelitian Ilmu Perpustakaan dan Informasi.Jakarta: JIP-FSUI.

Yesner, Bernice L \& Jay, Hilda L (1998).Operating and evaluating school library media programs: a handbook for administrators and librarians. New York: Neal-Schuman Publishers

\section{$\underline{\text { Author note }}$}

Hanna Latuputty was born in Jakarta in 1970. She has been working as a school librarian in the Secondary Resource Centre, The British International School, Jakarta, Indonesia for many years. She was educated at the University of Indonesia, majoring in Library Science. This is the second time she has presented a paper at an IASL conference after her previous paper that was presented last year at SLA/IASL Joint Conference, Dublin, Ireland. 
Reproduced with permission of the copyright owner. Further reproduction prohibited without permission. 